\title{
Structuri și strategii ale imaginarului poetic cernian. Condiționari și redefiniri interbelice
}

\author{
Drd. CARP (TANASIUC) Valentina-Luminița \\ Universitatea „Dunărea de Jos” din Galaţi
}

\begin{abstract}
At a time when Eminescu's lyric eclipsed in a natural and absolute lyrical way that succeeded him, yet the spiritual essence of the Romanian Anneam was not exhausted. On the contrary, there have also appeared poets who, without reaching Luceafar's size, have ascended to a higher level of the artistic expression due to the power of a talent and by capitalizing on acquisitions of modern French or German poetry. It is the case of Panait Cerna who was considered by the junimists and Mihail Dragomirescu a real genius. As it is known, the cernian poetry has had contradictory stages of reception, moving from maximal appreciation to some less favorable during the interwar period. He noted himself through the sincerity and winged momentum of the verse, through the sobriety of expression, but also by addressing the Eminescian themes. There were critics who considered Panait Cerna's poetry to be characterized by pure rationalism, lack of spontaneity, exaggeration of the use of comparison and symbolism. Then there was the emotion of ideas, the meditative sentiment corroborated with the pathetic attitude, the enthusiasm stemming from an overwhelming thirst for life, an overwhelming optimism. All these characteristics, as well as the social themes, in part of the narrative and pacifist fact, as well as the romantic nature of Cerna, oriented especially towards the erotic theme, to the embarrassment of his inner life and to his moral preoccupation, make the writer's poetry to be part of the representative literature for the second half of the 19th century - the beginning of the 20th century.
\end{abstract}

Keys words: Panait Cerna, Eminescianism, Romance, literary movement

Sfârșitul secolului al XIX-lea și începutul secolului al XX-lea, din punct de vedere istoric, corespunde perioadei de trecere a capitalismului în etapa imperialismului. Se observă accentuarea mizeriei și a exploatării maselor muncitoare, influența revoluției burghezo-moșierești din Rusia asupra dezvoltării mișcării muncitorești și asupra maselor țărănești, contrazicerile de clasă care se adâncesc. În acest context, ideile de luptă ale clasei muncitoare atrage, mai ales, pe acei intelectuali, care ducând o viață grea, cu o nesiguranță chinuitoare a zilei de mâine, se găsesc tot mai mult alături de popor. Astfel, ei sunt influențați în tematica lor creatoarea și în atitudinea față de viață. 
Pentru această perioadă se constată că, în literatură apare o creștere a interesului pentru ceea ce era legat de social, pentru problematica prezentului. Autorii vremii își exprimă punctul de vedere printr-o combatitivitate evindentă a scrisului. Lupta puternică între scriitorii legați de popor și scriitorii burgheziei și moșierimii, se comasează în jurul problemei țărănești și a problemei legate de rolul artistului în societate. Se disting scriitorii proveniți din rândurile intelectualității rurale care se simt ademeniți de arta cu conținut democratic, ei fiind ecoul glasului poporului pentru o viață mai bună.

Aceste idei devin expresie a preocupării crescânde pentru realitățile românești a artiștilor intelectuali. Aceștia se concentrează în jurul revistelor care îi cheamă „să producă o literatură pe gustul poporului, care să exprime felul de a vedea și de a simți, firea lui" ${ }^{\prime 17}$. Nu trebuie să pierdem din vedere faptul că multe dintre publicații erau purtătoare a unui program literar ce corespundeau anumitor curente literare. Pentru perioada aminitită, aceste curente erau „,curente ostile realismului, menite să abată lumea progresistă din drumul ei, oferindu-i în schimb diversiunea naționalistă. Aceste curente propagau izolarea artistului de popor, scepticismul și individualismul"174.

Raportându-ne perioadei, nu putem trece cu vederea că Panait Cerna a primit mult timp susținerea lui Titu Maiorescu pentru publicare și prin urmare, el s-a înscris, pentru început, în ideologia junimistă până la un anumit moment. Descoperiea lui Cerna de către Titu Maiorescu a permis o vadită influență pozitivă și i-a înlesnit afirmarea. ${ }^{175}$

Considerăm a fi necesare să aducem în prim plan câteva din prevederile programului viziunii junimiste și anume: lupta împotriva imposturii și stimularea aspirației către perfecțiunea artistic, pentru că aceste principii le regăsim în viziunea lui Cerna, poet care nu de puține ori a militat pentru a scrie poezii mai puține, dar de o calitate superioară. „Vreau să fiu cu totul liber(...),

${ }^{173} \mathrm{Micu}, \mathrm{D} .$, „Literatura română la începutul secolului XX”, Editura pentru literatură, București , 1964, pag. 9.

174 Ungureanu, M. L., „Panait Cerna și creația lui” comunicare ținută în cadrul filialei București a Societății de științe istorice și filologice din R.P.R, articol publicat în „Limba și literatura română"; București , 1955, pag. 288.

175 Dimitru Micu îl citează în lucrarea sa pe Mihail Dragomirescu (în 1895 devine redactor principal la revista Covorbiri) care cu exasperare se plângea că nu se mai putea vorbi de o literatura care să corespundă principiilor junimiste : „Îi luase pe toți, până și pe Maiorescu, curentul sămănătorist (Maiorescu trimitea la Sămănătorul în loc să le dea la Convorbiri literare, poeziile lui Vâlsan și Cerna care se citeau în salonul său)"., op.cit , pag. 29-30. 
vreau să scriu numai când mi se umple sufletul de lumină sau de lacrimi, vreau să public numai când socot eu cu cale"176. Chiar și mărturia prietenului său, Ioan Cosma, care a publicat în revista literară "Căminul", nr. 2 din iunie1913, susține dorința lui Cerna de a prezenta opera literară mai presus de nevoile ființei sale: „Pentru ce te grăbești? Crezi că tot ce se tipărește e bun? Crezi că e destul într-o poezie de zece strofe să fie abia una bună? Mulți din cei care scriu azi ar face lucruri mult mai bune, dacă ar munci mai mult, mai stăruitor și nu le-ar fi gândul mai întâi la tipar. Până acolo e o cale bună, și dacă nu ești pregătit cum trebuie, o faci în zadar. Decât în fiecare săptămână câte o poezie proastă, mai bine una pe an, dar să fie poezii"'177. Am putea spune că Panait Cerna a aderat atât de bine la junimism, încât l-a determinat pe George Călinescu să îl considere o victimă a concepțiilor lui Titu Maioescu. Această părere a exprimato explicit criticul literar atunci când s-au împlinit șaptezeci și cinci de ani de la nașterea poetului.

Un moment important în parcursul lui Panait Cerna este cel al întâlnirii cu Ion Luca Caragiale care îl îndrumă spre o mai bună înțelegere a problemelor țărănimii și astfel, poetul scrie o serie de poezii („Zile de durere”, „Floarea Oltului", „Poporul”), în care autorul își exprimă revolta și suferința " „în fața nedreptelor așezări, într-un spirit care descoperă influența clasei muncitoare asupra gândirii sale" ${ }^{\prime 178}$.

De pildă, versurile : „...Cine trece pe poteca dintre moarte și viață?/ E un neam, ce-avu pe vremuri o slăvită dimineață./ Neam al meu! A morții cruce tu o duci de voie bună:/ Printre veacurile mândre ai avut și tu cunună,/ Dar ai risipit-o singur, impărțând-o tuturora,/ Cum împarte raze cerul, când s-arată aurora..." evidențiază ideea glasului poetului purtător al revoltei neamului românesc.

Observăm că ideea sa poetică este limitată datorită concepției cerniane idealiste: arta este înainte de toate viață, și „de aceea ideea poetică nu este nicidecum o unitate abstractă, care are în cugetul nostru numai o umbrită nereală existență, ci o totalitate concretă, mișcătoare, individuală"179.

La celălalt pol, se situează programul care demonstrează originea și funcția socială a artei. Punctul de vedere diametral opus concepțiilor estetice idealiste, a teoriei „artei pentru artă" este susținut de „Contemporanul”, condus

\footnotetext{
${ }_{176}$ Panait Cerna citat de Valeriu Râpeanu în prefața ediției volumului „Floare și genune" Editura pentru literatură, 1968.

177 Ungureanu, M. L., op.cit., pag. 286.

178 Ibidem., pag, 290.

179 Ibidem., pag. 296.
} 
de C. Dobrogeanu-Gherea care reprezintă „principalul suport teoretic și un stimul al literaturii realist-critice în această perioadă"180.

Istoric vorbind, Panait Cerna apare într-o perioadă în care se resimt influențele romanismului și realismului. Nu putem să nu amintim punctul de vedere al lui Dumitru Popovici care spunea că romantismul se caracterizează prin trimful valorilor locale asupra valorilor clasice universale, printr-o literatură „a sentimentului și fanteziei." 181 Specialistul spunea că romantismul crează o lume proprie, în care determinante sunt sentimentul și fantezia, spre deosebire de realism, care pornește de la intuirea realității obiective. Pentru că în textele lui Cerna apar teme legate de popor, precum și ideea creării unei patrii ideale, îl putem înscrie pe Cerna ca fiind un romantic"182.

Poezii, precum "Orientale", „Lor", "Cavaler" sunt apreciate ca fiind sub influența romantismului epigonic. Cadru poeziior se conturează sumbru, iar cavalerii sunt prezenți ca fiind ,parcă, plictisiți, dezamagiți, sleiți din cauza vieții desfrânate, atmosferă care amintește de lirica trubadurilor, pe care Nicolae Manolescu o considera ca fiind începutul liricii românești a epocii moderne. ${ }^{183}$ Iată cum în "Orientale” se prezintă cavalerul: "Aveam chiulaf de smirnă, eram frumos şi tare,/ În Meca de-al meu nume ştia şi Mohamet-/ Dar prea-mi plăcură multe strânsori istovitoare"184.

Continuând analiza liricii cerniene de început, constatăm că poetul manifestă preferințe pentru peisajele stranii, enigmatice, „amurguri palide, nopți de păcură, bântuite de fulgere și furtuni, plate vechi, catedrale sumbre, turnuri tainice (...) o producție juvenilă"185, așa cum notează Valeriu Râpeanu. Citând un fragment din "Lor" : "Și azi adoratorii slăvesc, în el martirii :/ O glorie deo clipă în mijlocul furtunei/ Zvâcnind măreț din aripi se-abate ne-mblânzitî, / Î spulberă aievea petalele cununeil Și lasă numai spinii pe-o frunte veștejită." 186 constatăm asemănarea cu poezia eminesciană, „Epigonii”.

\footnotetext{
180 Ibidem., pag. 10.

181 Popovici, D., „Romantismul românesc”, Editura Albatros, Ediția I, Colecția Lyceum, București, 1972, pag. 6.

${ }_{182}$ Conform opinei lui D. Popovici: „Romantismului îi revine rolul de a fi descoperit poezia populară. Poporul va deveni astfel un teren nou pe care romanticii îl vor explora din plin." , op. cit., pag. 6.

183 Manolescu, N., „Istoria critică a literaturii române, vol. 1, Ed. Minerva, Bucureşti, 1990, pag. 6-10.

${ }^{184}$ Cerna, P.,, Poezii", Ed. Minerva, pag. 115.

185 Idem., Râpeanu, V., op. cit, pag. XIV.

186 Cerna, P., op. cit., pag. 112.
} 
Poetul romantic se simte solicitat de trecut sau de viitor, chiar atunci când „,se atașează realității”, continuă analistul și, de aceea, exitindem demersul nostru pentru a evidenția elementele realiste din imaginarul poetic cernian. Acestea sunt multe, chiar dacă ele nu apar bine conturate de la început. Setea de viață pe care Cerna o exprimă, cu atâta tărie, este o dovadă a realismului lui Cerna, susține M. L. Ungureanu. De altfel, și tematica pe care poetul dobrogean o reflectă în opera sa, este și ea, de factură realistă. Sunt poezii în care Cerna exprimă situația grea a țărănimii, unele care reflectă viața și trăirile personale: dorul de patrie, de iubită, de prietenii de care se despărțise, altele care descriu natura țării. Toate îl includ pe Cerna în rândul literaturii realiste.

Un aspect realist ce se impune a fi amintit în studiul nostru, este și prezența motivelor populare în universul poetic cernian. Coroborăm ideea cu influența sămănătoristă prin idilizarea vieții țăranilor și, constatăm că poezii sale impreisonează prin „farmecul deosebit, prospețimea și vioiciunea imaginilor sale, împrumutate din folclor-o dovadă, în plus, a dragostei de popor"187.

După cum se observă din parcursul său literar, Panait Cerna nu se poate alătura definitiv unui anumit program literar. Pentru început, a fost considerat ca fiind unul dintre cei care își încercau norocul în lumea literelor, mai ales că, primele sale versuri nu atrăgeau atenție și nici nu îl propuneau ca fiind „un poet excepțional de înzestrat". 188 Prima sa scriere este o traducere-imitație după Lenau, „Trecut”, care apare în revista cu profil de magazin a lui George Coșbuc, Foaie interesantă la 24 august 1897, când autorul semnează pentru prima dată ca Panait Cerna. Poezia are o valoare documentară și reflectă „orientarea gustului artistic în epocă" ${ }^{\prime 189}$.

Ulterior, după ce Panait Cerna ajunge la București, pentru a-și continua studiile la Facultatea de Filozofie ${ }^{190}$, spre sfârșitul anului 1901, își face debutul cu poezia „Noapte de vară” la revista Sămănătorul la direcția căreia se aflau

\footnotetext{
187 Ungureanu, M. L., „Panait Cerna și creația lui” comunicare ținută în cadrul filialei București a Societății de științe istorice și filologice din R.P.R, articol publicat în „Limba și literatura română"; București , 1955, pag. 293.

188 Râpeanu, V., op. cit, pag, XIV.

189 Bălan, D. I. postfață la volumul „Poezii” a lui Panait Cerna, Editura Minerva, București, 1981, pag. 179.

${ }^{190}$ Inițial, în 1900, Panait Cerna se înscrie la două facultăți: Facultatea de Fizico-Chimie și Facultatea de Filozofie, ambele din București, dar se retrage de la Faculatea de Științe.
} 
Alexandru Vlahuță și George Coșbuc și, abia apoi, când revista este condusă de Nicolae Iorga ${ }^{191}$ devine un colaborator statornic.

Deși în perioada 1900-1901, Panait Cerna publică frecvent în paginile revistelor Convorbiri literare și Revista modernă, totuși, poetul părăsește aceste reviste și se alătură mișcării noi, cea a sămănătorismului. Explicațiile privind această nouă orientare sunt de natură diversă. Un prim factor care 1-a influențat să părăsescă cultul junimist a fost de natură afectivă. Cum însuși Cerna recunoaște într-o scrisoare din 1913: „Unde aș putea găsi mai multă odihnă și mai multă dragoste decât la poetul tinereții și prietenul visurilor noastre", el a crescut în timpul liceului citind scrierile lui Vlahuță. O admirație deosebită nutrea și pentru George Coșbuc, așa încât, momentul în care poetul află că revista Sămănătorul se află sub coordonarea celor doi maeștri care i-au marcat tinerețea, este momentul care îl determină să trimită spre publicare scrierile sale noii reviste.

Pe de altă parte, dacă debutul lui Cerna stă sub semnul traducerilor și a imitaţiilor după diferiți scriitori străini, începând cu Lenau, Hugo sau Baudelaire, începând cu 1900, odată cu sosirea lui în capitală, scrierile sale se orientează spre viața tărănimii, a frămânărilor sociale ce se anunțau în epocă.

Poezia „Triumf” marchează o nouă etapă în creația lui Cerna. Temele și motivele de inspirație sămănătoristă sunt lense de identificat în textul poeziei: "În dimineți frumoase ca visul de-altă vremel Tot lanul e un zâmbet zglobiu și fericit,l Iar muncitoru-i vesel că-a izbutit să chemel O auroră nouă dintr-un pământ trudit"192.

Se observă tonalitatea veselă de început al versurilor încheiate cu sintagma purtătoare de mesaj al asupririi sociale.

\footnotetext{
191 Venit la conducerea revistei Sămănătorul, Nicolae Iorga afirma că, dând acestei publicații o anumită direcție, literatura putea fi concepută ca o parte constitutivă a unei mari acțiuni de „,îndreptare” socială și națională prin „răscolirea sufletească profundă care ar duce la o nouă viață morală, întinsă asupra instituțiilor, stăpână peste moravuri și exemplificată prin viața însăși asupra acelor cari o predică și, cărora li se impune cel mai devăvărșit rigorism etic, observat $\mathrm{cu}$ orice înfrângere a multelor ispite și cu orice jetfe individuale. Dar pentru această transformare spirituală, literatura însăşi, ajunsă, la unii tineri, rătăcitoare, atrăgând spre țărmuri streine de periculoasă robie și strecurând în suflete seducțiile unor civilizații prea înaintate ca să-și fi putut păstra frăgezimea inițială, era de cel mai de preț”; Iorga, N., „Istoria literaturii românești contemporane”, II , „În căutarea fondului", Editura Minerva, 1985, pag. 61.

${ }^{192}$ Cerna, P., op. cit, pag. 148.
} 
Dacă vorbim de sămănătorism, motivele așa-zis populare sunt asimilate în crearea unei viziuni stilizat-idilice rurale, iar aceasta este marcă esențială a sămănătorismului.

Alternarea imaginii tragice ale țărănimii de la 1900 cu sentimentul iubirii minimalizat, al cărei rol este adesea de a tempera intensitatea durerilor și inegalităților sociale, le găsim și în alte texte ale lui Cerna: "Către pace”, "Zile de durere" sau "Poporul”. Nedreptatea socială îl cutremură atât de tare, încât orientarea artistică spre viață și iubire, se transformă într-un puternică afecțiune durabilă pentru cauza celor nedreptățiți. Deși, departe de evenimentele din țară, iată că poetul trăiește empatic suferința celor de acasă și, deodată, nutrește sentimente de împotrivire, ură și chiar răzbunare, sentimente care sunt expuse astfel : „Apună toți! Tu nu lăsa să cadăl Din mâna-ți rece cumpăna divinăl Iar de-i pieri sub pietre ca profețiil De dincolo de negrul țărm al viețiil Inaltă spada ta nestrămutat"193.

În poezia "Poporul"poetul folosește interogația și repetiția, tocmai, pentru a atribui mai multă profunzime revoltei și durerii, pe care o trăiește atunci când prezintă viața de mizerie a țărănimii : „Cine-i cel ce se jelește că i-e

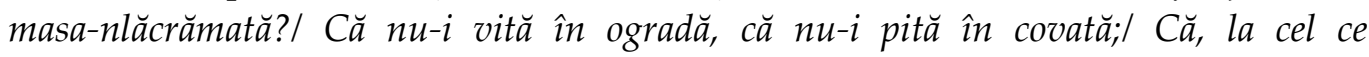
hodinește, chinul n-are nici o plată;/ Că la sânul mamei pruncul e-o pelincă înghețată,/ Că la cer nu e nădejde, că la inimi nu-i crezare / Că din leagăn i se cântă cântecul denmormântare?"194.

Având în vedere, perioada creației cerniene, apare firesc întrebarea: "Este Cerna un sămănătorist în sensul pur?"

Pentru a da un răspuns de luat în considerare se impune să enumerăm câteva aspecte. Dacă sub coordonarea lui Vlahuță și a lui Coșbuc se milita „să-și îndrepte luarea-aminte și toată dragostea lor spre popor"195, odată cu venirea lui Iorga la conducerea revistei, se schimbă puțin viziunea, întrucât se pare că pe directorul „Sămănătorului” îl preocupa „nu atât de a determina producerea unor operă care să rămână, cât de a antrena scriitorii, fie aceștia de mare talent sau numai de o orientare "sănătoasă", în acțiunea dusă de publicație. îl interesa, cu alte cuvinte, aspectul legat de scriitori (pe care îi dorea mai curând răspânditori

\footnotetext{
193 Cerna, P., op. cit., pag., 69.

194 Cerna, P., op.cit., pag. 112.

195 Micu, D. Apud Alexandru Vlahuță în articolul „Cărți pentru popor” apărut în numărul 3 din Sămănătorul , op.cit, pag. 51.
} 
decât creatori de cultură), eficiența imediată a producției literare și calitatea artistică preocupându-l, numai întrucât sporea această eficiență"'196.

Pornind de la aceste teze, Valeriu Râpeanu spune că Cerna s-ar înscrie în rândurile celor care promovau ideologia sămănătoristă a lui Vlahuță și Coșbuc prin poeziile sale de natură socială, dar nu promovează concepția lui Nicolae Iorga care vrea cultura ca factor al transformării conștiințelor, prin prioritizarea factorului moral, prin care se urmărea să se transforme societatea. De altfel, aducem în sprijinul opiniei sale o corespondență a poetului de la 1912 prin care acesta confesează lipsa de criterii estetice din sistemul critic promovat de Iorga : „Pare-se că-n literatura noastră nu a mai răsărit nimic mai de seamă... Sterilitate spăimântătoare-deși se scrie mai mult ca oricând. De când a lansat Iorga acea nefericită formulă, care confundă talentul cu fecunditatea, parcă toată ambiția celor tineri se-ndreaptă spre un singur gând să creeze nu ceva intens și stabil, ci cât mai repede și mai consumabil"197.

Un alt curent al vremii, curent care era purtător de "poezie nouă", împotriva curentului eminescian și sămanătorimului, era simbolismul. Din partea adepților simboliști, Cerna primește o recenzie nefavorabilă în Viața nouă, revistă literară care promova simbolismul. Curentul literar privea poezia românească ca un act artistic care se înstrăina de natură și urca "pe o treapă superioară a expresiei artistice, înnoite prin puterea unui talent de primă mărime, cu valorificarea unor achiziții ale poeziei franceze moderne, un anumit tip de sensiblitate." 198 Totuși, chiar și între simboliști Cerna a găsit susținători. ${ }^{199}$

Mijoacele artistice prin care Cerna exprimă conținutul ideilor sale poetice, am putea spune, că sunt de influență simbolistă. Această opinie poate fi explicată, pornind de la viziunea cerniană, potrivit căreia o valoroasă idee poetică devine mai expresivă, mai reliefată dacă ea este apropiată de sensibilitatea receptorului prin concretizarea imaginilor artistice. Așadar, o apropiere totală se realizează remarcabil prin utilizarea simbolurilor. Poezia „În peșteră", publicată în 1904, este reprezentativă pentru această atitudine a

\footnotetext{
${ }^{196}$ Ibidem., pag. 69.

197 Râpenu, V. Apud Cerna, P., „Studii și documente literare”, vol. IX, p.72 în prefață vol. "Floare și genune"; pag. XVI.

198 Ibidem., pag.227.

199 Prima recomandare pentru a publica poeziile într-un volum a fost făcută în Viața românească: „Ne permitem să ne exprimăm dorința ca d-l Cerna să-și adune versurile într-un volum pentru ca toți să ne putem da seama mai bine de fizionomia și inspirația poetului" citat de Râpeanu, V. în prefața, pag. XVII, op. cit.
} 
poetului. În acest text, ideea rezistenței este simbolizată de imaginea stalagmitelor și stalactitelor, lacrimile tavanului care au construit coloanele ce o susțin: „De pe tavane-ntunecate,/ Tăcute lacrimi cad mereu,/ Şi parcă tot sporesc din greu,/ Din mari izvoare depărtate". Autorul continuă textul cu "Tot astfel, lacrimi nesecatel În suflete ne-au picurat,l Şi de furtuni nenumăratel Viața noastră-a tremurat..."200 pentru a înfățișa corespondența cu viața omului.

Simbolurile poetului dobrogean se disting de cele ale simboliștilor. Dacă aceștia realizau o poezie abstractă, individualistă, neîncrezătoare, Cerna propune simboluri noi, vii, legate de viață, de aspirațiile omului, „cu sensuri pline de însemnătate umană și capabile de a trezi emoție artistică "201.

Însuși G. Ibrăileanu îl așeza din punct de vedere al poeziei sociale alături de Mihail Sadoveanu și Octavian Goga: „Acești trei scriitori reprezintă generația literară care apare în preajma anului 1900, în vremea crizei celei mari, când conștiința națională trezită și alarmată căuta pricina răului și o găsește în slăbirea simțului de conservare națională și în mizeria plină de întuneric a poporului de la țară" 202 .

Deși construită pe fundament eminescian, în unele situații opera Panait Cerna găsește resurse noi: credința în triumful final al zbuciumului stăruitor, elogiul învingătorilor și disprețul pentru soarta celor slabi, născuți a fi supuși. Acestea le găsim cu amprentă personală în poezii precum „Către pace”: „O, zee!/ $N u-i$ printre noi un suflet, să nu poartel Dorința pământescului tău rail Spre tinentindem dreapta toți, dar vai!"203 sau "Dura Lex": "Apoi le pleacă legii de fier: / Cei slabi să piară,/ Să nu le dea vieața nimic din câte-or cere!..." 204.

„Ideația nu i-a lipsit lui Cerna; i-a fost poate dăunătoare” 205 spune Pompiliu Constantinescu, astfel că poezia filosofică prezintă o viziune optimistă a lumii, dar „puterea plastică de a înveștmânta ideile în haina vie a închipuirii este redusă; reflexia rece, analitică nu e însoțită de explozia sentimentului, ce izbucnește, instinctiv, din matca zbuciumată a sufletului", continuă criticul literar. Aceste trăiri le identificăm în poezia filosofică a lui Cerna, poezie pe care Paul Zarifopol o consideră „,îndeosebi pentru oamenii de școală, valoarea

\footnotetext{
200 Cerna, P., op. cit., pag. 26.

${ }^{201}$ Ungureanu,M. L., op.cit., pag. 302.

202 Ibidem.

${ }^{203}$ Cerna, P., op. cit., pag, 65.

204 Ibidem.

${ }^{205}$ Constantinescu, P., „Scrieri ”, vol. 2, Ediție îngrijită de Constanța Constantinescu , Editura pentru literatură, 1967, pag.273.
} 
literară cea mai înaltă." 206 Poezia de idei subliniază și mai clar, preferința lui Cerna pentru dramatizarea reflecției lirice. Adam este omul care suportă pedeapsa divinității pentru a răscumpăra păcatul originar al iubirii cu prețul unui parcurs al aversiunii, dat descendenților săi, Cain și Abel : „Găsi-vei tu vrodată liman nemângâierii/ Să-i ierți pe-aceia care te-au hărăzit durerii?/ Noi nu știam, copile, că tu ai să plăteștil Cu chinuri clipa noastră de vrăji sărbătorești!"207.

Aspirația omului spre înalt prin confruntarea cu energiile din natură care-l limitează este un proces ce se desfășoară repetitiv, în mod prestabilit, iar încercările poetului de a dezmorți ideea prin imagini palpabile se transformă în anexe ale construcției demostrative a textului poetic. Astfel, prin versuri de tipul "Subt stânca fulgerată de la limanul mării,/ Nu-i undă să nu știe cuvintele pierzării;/ Și numai aripi negre bat apele ce sună,/ Numai chemarea morții răsare din furtună..."208, autorul ilustreză lupta dintre filosoful și poetul care vrea să-și pună optimismul în slujba creației proprii.

Se resimt, în textele cerniene, influențe mai mult sau mi puțin evidente eminesciene: „Dar, cum te pierzi întunecată, / Apune-trist a mea scânteie, -/Cu raza ta mă nasc deodată,/ Cu dânsa viața-mi se încheie" ${ }^{209}$. Totuși, ceea ce îi aparține lui Cerna este optimismul manierat dobândit pe cale didactică așa cum reiese din poezia "Ecouri": "Şi, dacă-n ora fermecatăl Asemeni zilelor păreți,/ E că trăiți, ca-n vis, deodatăl Atâtea mii şi mii de vieți..." ${ }^{210}$. In acest caz, Cerna face un compromis: transcrie, în aceeași formă, atitudinea sentimentală de la persoana întâi la persoana a III a, ceea ce face ca poetul nostru să se transforme din subiect, spectator.

Cu poezii, precum "Părâul și floarea" sau "Floare și genune”, deși se constată "emanciparea de sub tutela maestrului" 211 prin optimismul propriei creației, totuși, armonia versurile, variația conceptelor și a stilului din lirica cerniană persistă laolată cu influența lor. Cerna își sintetizează ideea în parafrazări, iar sensibilitatea, deși, este la intensitate mare, apare redată în fraze retorice, de cele mai multe ori de peste zece versuri. De exemplu, pentru a exprima starea de nerăbdare a sufletului în momentul întâlnirii dintre iubiți,

\footnotetext{
206 Zarifopol, P., „Poezia filozofică”, în „Pentru artă literară”, vol. I, Ed. Fundației culturale române", 1997, pag.200.

${ }^{207}$ Cerna, P., op.cit.16.

208 Ibidem., pag, 34.

209 Ibidem., pag.13.

210 Ibidem., pag. 11.

211 Stelian, C., „P.Cerna” în Revista „Universul Literar”, Anul LII, nr. 28, 1943.
} 
poetul în două fraze de unsprezece versuri reușește să creeze o singură imagine: „N-ai somn, în astă noapte de-așteptare!.../ Nici pace n-ai: din soarele de ieri, / O rază, un mănunchi de scânteieri,/ A-ntârziat în ochi, tremurătoarel Și nu se-nchid pleoapelearzătoare.../ Ți-i inima numai de visuri plină... / Ca-ntr-o biserică strălucitoare,/ Când se aprind făcliile la denii,/ Așa, deodată, s-a făcut lumină,/ În sufletul neadormit pe carel Se scutură un stol de dulci vedenii..."212.

Ceea ce-i rămâne definitoriu lui Cerna este avântul optimist din imnurile închinate iubirii. Prin "Chemare”, "Noapte”, "Șoapte”, „Despărțire” și „Torquato către Leonora", lirismul direct devine amprenta personală a autorului și astfel „Panait Cerna duce un pas mai departe poezia erotică pe care-o absorbise Eminescu și-o scoborâse parafrazările epigonilor săi" ${ }^{\prime 213}$.

Caracterul umanist al poeziei sale elogiind atât poezia, cât și poetul, întrun înalt cadru al dăruirii, este subliniat de Ion Pillat la o conferință din 18 ianuarie 1916 la Societatea „Amicilor orbi”: „poezia poate fi religioasă sau erotică, socială sau descriptivă, nu importă, ea rămâne umană. Cerna face parte din acești din urmă poeți. Și pentru el s-au ivit probleme și crize sufletești, dar ceea ce l-a interesat, $n$-a fost suferința personală, ci durerea omului care vibra într- însa"214.

În concluzie, făcând o analiză exhaustivă a operei lui Panait Cerna și a biografiei lui, se constată că este un caz aparte. El apare în literatura română ca fiind exponent al procesului de emancipare a poeziei românești de la sfârșitul secolului al XIX-lea- începutul secolului al XX-lea, aducând un aport propriu în ceea ce privește tehnica și lexicul, întrucât construcția trece pe primul plan, Panait Cerna fiind „un poet laborios”215, cum 1-a numit Constantin Ciopraga. Completăm ideea, cu finalul discursului lui Simion Mehedenți susținut la 24 mai 1913 care inventaria virtuțile lui Panait Cerna: „Ne-a rămas însă opera sacea mai frumoasă creațiune literară de la începutul veacului XX-lea în limba noastră; iar ea va fi izvor de veșnică bucurie pentru tot neamul românesc, cât va mai dura și graiul românesc" 216 .

\footnotetext{
${ }^{212}$ Cerna, P., op.cit., pag., 21.

${ }^{213}$ Constantinescu, P., pag. 274.

${ }^{214}$ Cerna, D., „Panait Cerna, scepticul luminos”, Editura Casa Cărții de Știință, ClujNapoca, 2009, pag. 337 apud Pillat, I. „Poezia lui P.Cerna”, București, Institutul de Arte Grafice Carol Gobl, 1916, pag. 5.

${ }^{215}$ Ciopraga C., „Literatura romănă între 1900 și 1918”, Ed. Junimea, 1970, pag. 270.

${ }^{216}$ Cerna, D., op.cit., pag. 330 apud Simion Mehedinți , „Soveja”, „Comemorarea lui P. Cerna ", „Panait Cerna, scepticul luminos”, Editura Casa Cărții de Știință, Cluj-Napoca, 2009.
} 


\section{Bibliografie:}

Antofi, Simona, General Dictionary of Romanian Literature - Obverse and Reverse Critical Reception, în Oana Cenac (coord., edit.), International Conference of Common Vocabulary/Specialized Vocabulary: Manifestations of Creativity of Human Language, 6-7 iunie 2014, publicate în volumul MANIFESTARI ALE CREATIVITATII LIMBAJULUI UMAN, 2014, p. 13-19, ISBN:978-606-17-0623-5, Accession Number WOS:000378446400001;

Cerna, D., „Panait Cerna, scepticul luminos”, Editura Casa Cărții de Ștință, ClujNapoca, 2009;

Cenac Oana, Discurs ideologic în "Ateneu” 1965, Actele conferinţei internaţionale Lexic comun / Lexic specializat. Democratizarea cunoașterii" sau migrația lexicului specializat spre lexicul comun, ediția a X-a, Universitatea „Dunărea de Jos” din Galați, Facultatea de Litere, Centrul de Cercetare Comunicare interculturală și literatură, 19 - 20 mai 2017, publicată în Analele Universității „Dunărea de Jos” din Galați, Fascicula XXIV Lexic comun / lexic specializat, revistă indexată in bazele de date internaționale EBSCO: https://www.ebscohost.com/titleLists/cmscoverage.pdf, MLA (Modern Language Association, New York, www.mla.org) MLA International Bibliography \& Directory of Periodicals, CEEOL și Fabula. La recherche en littérature (www.fabula.org), anul X, nr. 2(18) /2017, Editura Casa Cărții de Ştiință, Cluj-Napoca, 2017, ISSN 1844-9476, p. 31-48.

Cenac Oana, General aspects of current political terminology, în Lexic politic - discurs politic, 2014, p.124-130, ISBN:978-606-17-0633-4, WOS: 000378358200007.

Cerna, P. „Floare și genune” Editura pentru literatură, 1968;

Constantinescu, P., „Scrieri ”, vol. 2, Ediție îngrijită de Constanța Constantinescu , Editura pentru literatură, 1967;

Ifrim, Nicoleta, Theoretical Aspects of Identity Discourse in Post-totalitarian Cultures, în Procedia-Social and Behavioral Journal (ISSN: 1877-0428) (ISSN: 1877-0509), vol.63/2012 ELSEVIER, pp.35-40, DOI 10.1016/j.sbspro.2012.10.007, http://www.sciencedirect.com/science/journal/18770428/63/supp/C,

WOS:000361477200006;

Iorga, N., „Istoria literaturii românești contemporane”, II, „În căutarea fondului", Editura Minerva, 1985;

Manolescu, N., „Istoria critică a literaturii române, vol. 1, Editura Minerva, Bucureşti, 1990;

Micu, D., „Literatura română la începutul secolului $X X^{\prime}$, Editura pentru literatură, București, 1964;

Stelian, C., „P.Cerna” în Revista ” Universul Literar”, Anul LII, nr. 28, 1943; 
Ungureanu, M. L., „Panait Cerna și creația lui” comunicare ținută în cadrul filialei București a Societății de științe istorice și filologice din R.P.R, articol publicat în "Limba și literatura română", București , 1955;

Zarifopol, P. „Poezia filozofică”, în „Pentru artă literară”, vol. I, Editura Fundației culturale române", 1997. 